\title{
Processing approaches to reducing allergenicity in proteins
}

\author{
E.N.C. Mills, J. Moreno, A Sancho and J.A. Jenkins, Institute of \\ Food Research, UK and H.J. Wichers, Wageningen UR, The \\ Netherlands
}

\subsection{Introduction: food allergens}

In order to take a systematic approach as to how allergens may be removed from foods using approaches such as raw material selection or physical processing it is important to have a clear understanding of what constitutes an allergen. Taken in its strictest sense an allergen is defined as a macromolecule to which immunoglobulin $\mathrm{E}$ ( $\mathrm{IgE}$ ) binds. IgE responses are generated as part of the normal immune reaction to parasitic infections, but for reasons that are only partly understood can also be generated following exposure to environmental agents, such as pollen, dusts, and foods. On a subsequent encounter the allergen is able to cross-link surface bound $\operatorname{IgE}$ molecules located on basophile or mast cells, causing them to release preformed inflammatory mediators, including histamine. It is these mediators which actually cause the symptoms manifested in an allergic episode which usually occurs quite rapidly following exposure and is consequently classified as a Type I hypersensitivity reaction. Such reactions are distinct from food intolerances, which are reproducible, sometimes non-immune-mediated, reactions whose symptoms can take days to manifest themselves. An example of such a condition is the gluten intolerance syndrome, Coeliac disease, and whilst the gluten proteins which trigger it are not IgE-binding proteins, some workers refer to them as allergens, and they are treated as such in the WHO Codex Alimentarius Commission Labelling regulations.

Almost all allergens are proteinaceous in nature, as other polymers, such as polysaccharides, usually generate only poor antibody responses. There is 
limited evidence that plant polysaccharides can act as allergens, although it is often unclear whether such reactions result from protein contamination, as some plant cell-wall associated proteins have been found to be allergens (Lunardi et al., 2000). IgE binding per se is not indicative of an allergen functioning to elicit an allergic response. Thus, peanut allergic patients have serum IgE which cross-reacts with soy proteins but generally suffer no allergic reaction when they eat soya containing foods (Eigenmann et al., 1996). Multivalency is essential for an allergen to trigger release of histamine and other inflammatory mediators and it is thought that whilst carbohydrate determinants are widely found and can elicit IgE responses, they are largely monovalent and hence are generally unable to trigger histamine release (Alberse, 1998). On the basis of the frequency of reaction, allergens have also been classified as being either major (an allergen recognised by IgE from 50\% of a group of at least ten allergic patients), or minor (Larsen and Lowenstein, 1996). However, such a classification gives no indication of allergenic potency and is questioned by some (Alberse, 2000).

Only around eight types of foods are responsible for causing the majority of food allergies, including cow's milk, egg, peanuts, tree nuts, wheat, fish, shellfish and soya (Bush and Hefle, 1996). What follows is a brief overview of these allergens, followed by a summary of their properties which are relevant to the issues of reducing their levels in foods.

\subsection{Protein allergens of animal origin}

\subsubsection{Cow's milk}

Both whey proteins, which include $\beta$-lactoglobulin and $\alpha$-lactalbumin, and caseins have been characterised as allergenic fractions (Wal, 1998). $\beta$ lactoglobulin is a member of the lipocalin superfamily, to which a number of other inhalant allergens belong (Mantyjarvi et al., 2000). It is highly resistant to proteolysis and is taken up in an intact form by the gut in experimental systems, a factor which is thought to contribute to its allergenicity. The IgE epitopes have been identified in $\beta$-lactoglobulin with four main $\operatorname{IgE}$ binding regions being located on the more mobile surface loops of $\beta$-lactoglobulin. Caseins include the $\alpha_{\mathrm{s} 1^{-}}, \alpha_{\mathrm{s} 2^{-}}, \beta$ - and $\kappa$-caseins, which have a low level of sequence identity but are all relatively unstructured phosphoproteins with a high proline content. Caseins retain their $\operatorname{IgE}$ reactivity irrespective of their phosphorylation state. The $\operatorname{IgE}$ binding regions have been identified in caseins with six major and three minor epitopes found for $\alpha_{\mathrm{s} 1}$-casein (Chatchatee et al., 2001a), four major and six minor epitopes found for $\alpha_{\mathrm{s} 2}$-casein (Busse et al., 2001), six major and three minor epitopes for $\beta$-casein and eight major epitopes for $\kappa$-casein (Chatchatee et al., 2001b). These epitopes are thermostable, possibly a reflection of the rheomorphic character of this protein. IgE binding to two epitopes on $\alpha_{\mathrm{s} 1}$-casein, one on $\beta$-casein and two on $\kappa$-casein correlated with persistent cow's milk allergy (Jarvinen et al., 2002). 


\subsubsection{Egg}

The major allergens of egg originate from the white and include the glycoproteins ovomucoid ( Gal $d$ l) and ovalbumin ( Gal d 2), which make up $10 \%$ and $50 \%$ of egg white protein respectively, together with two minor allergens, ovotransferrin (Gal d 3) and lysozyme (Gal d 4). Whilst around 25\% of the mass of ovomucoid comprises carbohydrate, none of the seven $\operatorname{IgE}$ binding regions encompass glycosylation sites. The nature of the IgE epitopes appear to change during the development of egg allergy, with conformational epitopes appearing in newly acquired sensitivities and linear epitopes being more important in long-standing egg allergy. Seven IgE-binding regions have been identified in ovalbumin clustering at the $N$ - and $C$-terminal regions, which are resistant to enzymic digestion and denaturation (Cooke and Sampson, 1997).

\subsubsection{Fish}

The major fish allergen is parvalbumin ( $\mathrm{Gad}$ c 1), a calcium buffer protein in fast muscle unique to fish and amphibians (Bugajska-Scretter et al., 1998). It is highly conserved across fish species, a factor responsible for the cross-reactive nature of allergens in fish such as cod, salmon, mackerel, herring and plaice. Parvalbumin is a member of the EF-hand superfamily of proteins, as it contains an EF-hand calcium binding motif. Gad $c 1$ has five IgE-binding regions evenly distributed along the length of the protein, one of which encompasses one of the $\mathrm{Ca}^{2+}$ binding sites, and indeed the holo-form is more IgE-reactive. Like other calcium binding proteins it is thermostable, its stability increasing when it is binding $\mathrm{Ca}^{2+}$.

\subsubsection{Shell-fish and seafood}

Another heat-stable muscle protein, tropomyosin, is the major allergen in crustacea and other shell-fish. As well as being found in cooked meat, the allergen is highly soluble and leaches into cooking water, or even spray found in fish markets. Tropomyosins show a high degree of homology across commonly edible crustaceans, with lower homology to vertebrate tropomyosins. There is cross-reactivity between the tropomyosins of crustacea and mollusca (Leung et al., 1996). Two main linear IgE-binding sites were identified in the shrimp allergen, Pen $i 1$ (Shanti et al., 1993). The $N$-terminal epitope showed very little identity with vertebrate tropomyosins while the C-terminal epitope was similar except for first two residues, which are conserved as FL in arthropods and $\mathrm{HI}$ in vertebrates, and were thus suggested to be crucial for IgE binding (Leung et al., 1996).

More recently, studies of Pen a 1 have defined eight partially overlapping epitopes (Reese et al., 1997; Ayuso et al., 2002). These epitopes show some correlation with the imperfect repetitions in the sequence of tropomyosin. The first epitopes of Pen a 1 and Pen i 1 overlap while the initial phenylalanine of the second epitope of Pen $\mathrm{i} 1$ is the last residue of the fourth epitope of Pen a 1 . 
Ayuso et al. (2002) noted that the epitope regions of Pen a 1 are well conserved in the tropomyosins of other invertebrates and suggested that this causes the clinically relevant cross-reactivity between various types of seafood including shrimps, lobsters, crab, squib and abalone, as well as inhalant allergens from insects such as cockroaches. By contrast, there is no cross-reactivity between IgE from shell-fish allergic individuals, and vertebrate muscle tropomyosins.

\subsection{Protein allergens of plant origin}

\subsubsection{Wheat}

Whilst there is a widespread perception that wheat is responsible for a large proportion of food allergies, the role of cereal proteins in food allergy is poorly characterised, although their role in occupational allergies such as baker's asthma and in coeliac disease is well defined. Most wheat allergens are either prolamin storage proteins or belong to the family of $\alpha$-amylase/trypsin inhibitors. The former are an extensive family of proteins characterized by their solubility in aqueous alcohols and insolubility in dilute salt solutions, $M_{\mathrm{r}} \mathrm{s}$ range from about 10,000 to 100,000 and are rich in proline and glutamine (Shewry and Tatham, 1990, 1999). Almost all contain regions that consist either of repeated peptide motifs or are enriched in specific amino acids (especially proline and glutamine) and are usually accompanied by one or more nonrepetitive domains that contain most or all of the cysteine residues. Allergens belonging to the prolamin seed storage proteins have been identified, particularly in relation to atopic dermatitis (Maruyama et al., 1998; Takizawa et al., 2001; Tanabe et al., 1996b) including a $\gamma$-gliadin and an $\alpha$-gliadin involved in exercise induced anaphylaxis (Palosuo et al., 1999). Allergens belonging to the cereal inhibitor family can be involved in both respiratory and food allergies, the most active in baker's asthma being the glycosylated forms of subunits of tetrameric $\alpha$-amylase inhibitors (Carbonero and García-Olmedo, 1999). The same allergens have been characterised in orally sensitised wheat allergic individuals, although only one $M_{\mathrm{r}} \sim 15,000$ subunit was involved (James et al., 1997).

\subsubsection{Peanuts, nuts, seeds and soybean}

The major allergens in these plant-based foods are generally the seed storage proteins, and comprise the $11 \mathrm{~S}-12 \mathrm{~S}$ (legumin-like) and $7 \mathrm{~S}$ (vicilin-like) globulins, and the $2 \mathrm{~S}$ albumins. The globulins have homologous threedimensional structures and are members of the cupin superfamily, sharing a $\beta$-barrel structure (Lawrence et al., 1994, Dunwell, 1998). Oligomeric proteins, produced from multigene families, legumin-like globulins have $M_{\mathrm{r}} \mathrm{s}$ of about $300,000-450,000$ and consist of six subunits of $M_{\mathrm{r}}$ about 60,000 , associated by non-covalent forces. Each subunit is post-translationally processed to give rise to acidic $\left(M_{\mathrm{r}}\right.$ about 40,000$)$ and basic $\left(M_{\mathrm{r}}\right.$ about 20,000$)$ chains, which are linked 
by a single disulphide bond. In contrast the $7 / 8 \mathrm{~S}$ globulins are typically trimeric proteins of $M_{\mathrm{r}}$ about 150,000-190,000, with subunit $M_{\mathrm{r}}$ s ranging from about $40,000-80,000$ but usually about 50,000 . Whilst the $11 / 12 \mathrm{~S}$ globulins are rarely, if ever, glycosylated, the vicilins frequently are.

Major allergens belonging to this group of proteins include the $11 \mathrm{~S}$ and $7 \mathrm{~S}$ globulins of soy (Shibasaki et al., 1980, Burks et al., 1988; Rabjohn et al., 1999) peanut (Burks et al., 1991, 1992), together with the 7S globulins of walnut (Teuber et al., 1999), sesame (Beyer et al., 2002a), cashew nut (Ana c 1) (Wang et al., 2002), hazelnut (Beyer et al., 2002b) and one of the subunits of the proteolytically processed 7S globulin of lentil (Sánchez-Monge et al., 2000). The 11S globulins have also been confirmed as an allergen in almond (also known as almond major protein, AMP) (Roux et al., 2001) and implicated as allergens in coconut and walnut (Teuber and Petersen, 1999).

$2 \mathrm{~S}$ albumin storage proteins may accompany the globulins but are much smaller proteins. Synthesised as single chains of $M_{\mathrm{r}} 10,000-15,000$ they are post-translationally processed to give small and large subunits which usually remain joined by disulphide bonds. $2 \mathrm{~S}$ albumins were among the first plant proteins to be described as allergens, over 50 years ago (Youle and Huang, 1981), they have been identified as allergens from mustard seed, Sin a 1, (Menendez-Arias et al., 1988), Bra j 1e (Monsalve et al., 1993), peanut (Burks et al., 1992), Brazil nut (Pastorello et al., 1998b), almond (Poltronieri et al., 2002), sunflower (Kelly et al., 2000), walnut (Teuber et al., 1998) and, most recently, sesame (Pastorello et al., 2001b). It has also been reported that the $2 \mathrm{~S}$ albumins of soy (Shibasaki et al., 1980) and chickpea (Vioque et al., 1999) are allergens.

The non-specific lipid transfer proteins (ns LTPs) are also members of the prolamin superfamily and have been characterised as food allergens from several nut and seed species, including peach, apple, hazelnut and sesame (Pastorello et al., 2001a; Sánchez-Monge et al., 1999). Whilst not especially abundant in fruits or seeds, ns LTPs can become concentrated in epidermal tissues and associated with the waxy layers (Douliez et al., 2000). They are thought to play a role in the synthesis of the waxy cuticle of fruits and have been designated pathogenesis related (PR) proteins as they form part of a broad spectrum of proteins, which are synthesised in plants in response to infection, damage or stress.

The cysteine protease superfamily includes a major soybean allergen. This is the $34 \mathrm{kDa}$ protein, which was originally misidentified as an oil body-associated protein, and is known variously as Gly m Bd 30K, Gly m 1, or P34 (Ogawa et al., 1993). Gly $\mathrm{m} \mathrm{Bd} 30 \mathrm{~K}$ is probably not an active protease but may be part of the PR system of soya (Ji et al., 1998). However, Act c 1 is the major allergen from kiwi and is an active cysteine protease (Pastorello et al., 1998a). Gly $\mathrm{m} \mathrm{Bd}$ $30 \mathrm{~K}$ exists as complex of molecular weight $>300,000$, as it becomes disulphidelinked to the $\alpha, \alpha^{\prime}$ subunits of the soya globulin $\beta$-conglycinin (Ogawa et al., 1993; Samoto et al., 1996) and is $N$-glycosylated (Bando et al., 1996). 


\subsubsection{Allergens involved in cross-reactive allergy syndromes}

Individuals sensitised to inhalants such as pollen and latex may suffer from food allergies as a result of $\operatorname{IgE}$ developed to pollen or latex proteins then binding to homologous proteins found in foods. These have been well characterised for pollen-fruit/vegetable and latex-fruit allergies (Breiteneder and Ebner, 2000) as well egg allergies in bird fanciers who become sensitised to feathers (Anibarro et al., 1991) and dust mite allergies which can result in reactions to arthropod and mollusc foods such as snails (Leung et al., 1996).

\section{Pollen-fruit/vegetable allergy syndrome}

The major birch pollen allergen, Bet $\mathrm{v}$ 1, is related to a class of putative plant defence proteins (PR10) and results in dietary reaction to proteins in a range of fruit (including Mal d 1 of apple and Pru av 1 of cherry) and vegetables (including Api g 1 of celery, Dau c 1 of carrot). Although the biological role of PR10 proteins has not been established, they are presumed to be defensive (Hoffman-Sommergruber 2002). A further type of PR protein (PR-5) which is related to the sweet protein thaumatin is an allergen in fruits such as apple (Mal $\mathrm{d} 2$ ), cherry (Pru av 2). A second major pollen allergen, Bet $v 2$, is a profilin, a protein which binds to the actin cytoskeleton of cells. Sensitisation to this pollen protein results in allergic reactions to proteins in various plant foods including hazelnut, peanut (Ara h 5), soybean (Gly m 3), celery (Api g 4) and pear (Pyr c 4).

\section{Latex-fruit allergy syndrome}

Inhalation of two other PR-type proteins from latex can also result in dietary allergy to related proteins in fruit and vegetables. These are PR-2/Hev b $2(\beta 1,3-$ glucanase) and PR-3/Hev b 6 (class II chitinases) which result in cross-reactive allergies to foods such as avocado, chestnut, banana, fig, kiwi and other foods.

\subsection{General properties of protein allergens: abundance, structural stability and epitopes}

Allergens found in foods that cause allergies as a result of oral sensitisation seem in general to possess two properties, abundance in the food and/or structural stability. Thus many of such food allergens are found in major foods which comprise a large proportion of the human diet (eggs, milk) or are abundant proteins in a food. Thus, the major allergens of milk, egg, fish, and peanuts are all highly abundant, comprising $25-50 \%$ of the protein in the original food. Many allergens are stable proteins, resisting thermal denaturation and/or proteolysis and include many cupin allergens (Mills et al., 2003), members of the prolamin superfamily such as the ns LTPs (Douliez et al., 2000), cow's milk $\beta$-lactoglobulin (Wal, 1998), cod parvalbumin (Bugajska-Scretter et al., 1998) and hen egg ovomucoid (Cooke and Sampson, 1997). Whilst many food allergens share both these attributes, some such as the caseins, are abundant but 
proteolytically labile proteins, whilst the ns LTPs are not especially abundant but are remarkably stable.

One reason underlying such common characteristics, may be that for a food allergen to sensitise an individual via the gastrointestinal tract it must possess properties which preserve its structure from the degradation in the gastrointestinal tract, such as resistance to low $\mathrm{pH}$, proteolysis, and surfactants such as bile salts. This is required to ensure that sufficient intact (or semi-intact) protein survives to be taken up by the gut and sensitise the mucosal immune system. However, allergens involved in cross-reactive allergy syndromes do not share such properties, but have more in common with inhalant allergens, being readily soluble in physiological buffers, being more thermolabile and readily digested proteins. Consequently, whilst they are able to elicit an allergic reaction they are often unable to sensitise an individual through ingestion. Susceptibility to digestion by protease has become a matter for debate in recent times and has been reviewed elsewhere (Mills et al., in press). Thus, fruit allergens belonging to the Bet $\mathrm{v} 1$ family of proteins which are involved in the pollen-fruit allergy syndrome are considered to be 'incomplete' allergens, as ingestion of fruit itself does not stimulate an $\operatorname{IgE}$ response, but does trigger histamine release from mast cells loaded with IgE to the birch pollen allergen Bet v 1 (Alberse, 2000).

\subsubsection{Epitopes and allergenicity of food}

Allergic reactions to foods are in fact allergic reactions to individual food components, in most cases proteins (Lehrer et al., 1996), but sometimes also carbohydrates (Jankiewicz et al., 1997). Allergens are often proteins with molecular masses as determined by SDS PAGE of 8-70 kDa. They may occur as larger multimers such as the peanut allergen Ara h 1 (Lehrer et al., 1996; Hefle, 1996; Taylor and Lehrer, 1996). Small regions of allergens, called epitopes (also known as B-cell epitopes), provoke the IgE-mediated allergic response (Lehrer et al., 1996; Hefle, 1996; Taylor and Lehrer, 1996; Taylor and Hefle, 2001).

Food allergens and their epitopes may be relatively resistant and able to withstand the effects of food processing and digestion (Taylor et al., 1987, Taylor and Hefle, 2001). The integrity of conformational epitopes is not exclusively determined by their primary structure. These epitopes are also characterised by the tertiary structure of a protein, and their integrity therefore depends on the thermodynamics that determines tertiary protein structure (Lehrer et al., 1996).

Despite the relative stability of allergens and epitopes to digestion and processing, knowledge of the epitope structure and the factors that determine its chemical and physical stability can lead to the design of specific and well directed approaches to decrease food allergenicity. Structural similarities between allergens and their epitopes may lead to the development of more generic approaches to alter their allergenicity. In this context, it is of paramount importance that better knowledge is gained on structural similarities between 
allergens from various origins, for instance as described by Mills et al. (2003). Plant allergens can be classified in a relative limited number of groups, based e.g. on their biological function as storage proteins (peanut, soy, many tree nuts) or as PR-related proteins (Midoro-Horiuti et al., 2001; HoffmannSommergruber, 2002). The emerging genomics and proteomics technology is likely to accelerate the structural study of allergens.

In addition to the B-cell epitopes which correspond to the sites on a protein which are recognised by an antibody, another set of epitopes, known as T-cell epitopes are necessary for generation of humoral immune responses. They are generally short continuous sequences of 12 to 18 residues (Lehrer et al., 1996, Matsuda and Nakamura, 1993) and are diverse in nature (Cooke and Sampson, 1997; Mizumachi and Kurisaki, 2003). As a consequence of their short length food processing is much less likely to affect them than the $\operatorname{IgE}$ (B-cell) epitopes, and this is borne out, at least for enzymatic hydrolysis which can destroy B-cell but not T-cell epitopes in, for example, peanut proteins (Hong et al., 1999). However, it is clear that chemical modification of protein will reduce the number of possible T-cell epitopes, since the HLA molecule binds most modified peptides only weakly, and hence processing induced changes, such as Maillard modifications, may have the potential to inactivate some T-cell epitopes.

\subsection{Factors affecting protein allergenicity in raw foods}

\subsubsection{Genetics and breeding for low allergen foods}

As the major food allergens of animal origin seem to be highly conserved across the limited number of species which are consumed, breeding is not a viable option for reducing the levels of such allergens. Thus $\beta$-lactoglobulin is similar in cow's, goat's and sheep's milk and triggers reactions in cow's milk allergic individuals. Similarly the conservation of major fish and shell-fish allergens means that in general individuals become allergic to many fish species (Pascual et al., 1992).

The situation is more promising with plant-based foods. A number of plant protein allergens belong to multigene families where a number of isoforms differing in only a few amino acid residues may be present. In addition the expression of different isoforms may vary between cultivars. Substitution of Ser $^{111}$ with a Pro residue removed a pollen-fruit cross-reactive epitope in the apple allergen Mal d 1, indicating that point mutations in critical regions can be highly effective in removing IgE reactivity from an allergen (Son et al., 1999). An analysis of IgE-reactivity showed that Mal d 1 IgE binding was demonstrably higher in certain apple cultivars and that one variant, Mal $d$ la, had a higher IgE-binding capacity than another variant Mal $d 1 b$, which differed by only 15 amino acid residues. In kiwi fruit the levels of actinidin have been shown to vary widely between cultivars, suggesting that breeding may be a way of reducing the allergens in these fruits (Nishiyama and Oota, 2002), although 
there appears to be little cultivar variation in Gly $\mathrm{m} \mathrm{Bd} 30 \mathrm{~K}$ in soybeans (Yaklich et al., 1999).

An extensive screen of peanut accessions from S America and the USA for IgE-binding protein content, using pooled human allergic sera showed a wide variation in allergen levels. Two accessions were identified with lower allergen contents, although no 'null' allergen lines could be identified (Dodo et al., 2002). Thus there is undoubtedly the potential in the future for plant breeders to select for reduced allergenicity in raw plant-based foods.

\subsubsection{Low-allergen plant foods produced by genetic modification}

In the past few years, a number of examples have been described of successful attempts to reduce allergenicity via the application of molecular genetic techniques. Almost a decade ago, the major allergen from rice, an $\alpha$-amylase inhibitor, was knocked out by means of antisense-technology (Adachi et al., 1993; Tada et al., 1996). The newly acquired trait was stably inherited in at least three generations (Tada et al., 1996).

In many cases, cross-reactions between respiratory and food allergies exist. In the case of rice pollen allergy, immunoblotting revealed major allergens of 16, 26 and $32 \mathrm{kDa}$ (Tsai et al., 1990). Also situation cross-reactivity may be a significant factor in the pathology, as cross-reactivity between major allergens from rice and rye grass (Lolium perenne) has been demonstrated (Xu et al., 1995). The $16 \mathrm{kDa}$ allergen may be a connecting factor in allergic crossreactions between various members of the cereal Poaceae family, including maize (Urisu et al., 1991; Yamada et al., 1991). Recently, a genetically engineered variety of Lolium was described, in which the Lol p 5 allergen was knocked out via an antisense construct. Hypoallergenicity was demonstrated with immunoblots and low IgE-binding (Bhalla et al., 1999).

To decrease the allergenicity of soy, both mutagenesis and genetic modification have been applied successfully. The major allergens in soy are the storage proteins Gly m Bd $60 \mathrm{~K}$, Gly $\mathrm{m}$ Bd $30 \mathrm{~K}$ and Gly $\mathrm{m} \mathrm{Bd} 28 \mathrm{~K}$. The allergenicity of soybean and soybean products was reduced by a combination of mutation breeding, physico-chemical treatment and enzymatic digestion. Gly $\mathrm{m}$ Bd $60 \mathrm{~K}$ and Gly $\mathrm{m}$ Bd $28 \mathrm{~K}$ were eliminated by development of a mutant line, while the strongest allergen, Gly $\mathrm{m} \mathrm{Bd} 30 \mathrm{~K}$ was salted out or destroyed by enzymatic digestion. Approximately $80 \%$ of soy sensitive patients could ingest products that were produced from this hypoallergenic soy, without adverse reactions (Ogawa et al., 2000).

Very recently, a hypoallergenic soy variety was developed making use of antisense technology, in which Gly m Bd 30K was knocked out. Although preliminary tests with patient's sera could not detect the allergen in knockout beans, more tests are needed to investigate the claimed hypoallergenicity, or decreased allergy-causing. The yield of the new variety, based on cultivar 'Jack', looked normal. The plants developed normally, the seeds set at a normal rate, and seemed to have the same protein and oil composition suggesting that 
silencing P34 does not interfere with the plant's agronomic characteristics (Suszkiw, 2002).

For peanut, attempts have been made to reduce the allergenicity of Ara h 1 via replacement of epitope-located amino acids (Burks et al., 1999). Indeed reduced IgE-binding was achieved. As most allergenic epitopes are located in the hydrophobic regions of Ara $\mathrm{h} 1$ that are involved in the integrity of the trimeric structure, the possibility cannot be ruled out that the change in epitope structure affects the physiological functioning of the protein (Bannon et al., 1999). In addition, peanut allergy will remain a notoriously recalcitrant food allergy since peanut contains a number of other major allergens that are recognised by large groups of patients (Kleber et al., 1999).

From the foregoing examples, the conclusion can be drawn that DNA technology can be successfully applied for reduction of allergenicity of raw materials for food production. However, for foods where there are multiple allergens which are highly abundant in edible plant tissues, the costs of producing the hypoallergenic food may be prohibitive, and there would likely to be regulatory hurdles as such a modified food will, of its very nature, not be 'substantially equivalent' and hence undergo even closer scrutiny in the regulatory process before it could reach the market place.

\subsubsection{Post-harvest storage}

Many plant-based foods are stored prior to further processing or consumption. This is particularly important in fresh fruits and vegetables. Allergen levels appear to increase in apples following harvest and during storage at $4^{\circ} \mathrm{C}$ over 130 days probably because of their association with the ripening process, and the fact that they are 'PR' proteins and hence synthesised in response to environmental stress. This is especially well characterised in apples, where ripening has been shown to result in an increase in allergens (Vieths et al., 1993). Storage under modified atmospheres can reduce these increases in allergen levels, as might be anticipated from its ability to delay fruit ripening. Such storage was also found to result in changes, especially in the thaumatinlike protein, a minor apple allergen which is also a PR-protein (Li-Shan et al., 1995). Recent work in our laboratory has shown that levels of the apple allergens Mal d 1 and Mal d 3 (a ns LTP allergen) both decrease on storage of fruits for 3-5 months under modified atmosphere. However this may not extend to all climacteric fruits, as a limited study on the storage of mango fruits showed no alteration in levels of allergens (Paschke et al., 2001).

\subsection{Reducing protein allergenicity during food processing}

\subsubsection{Removal of allergens}

Processing has the potential to reduce the allergenicity (IgE-reactivity) of foods in two ways. Firstly, in plant-based foods where allergens may only be 
expressed in certain tissues, the allergen load of a final processed food can be reduced by removing the tissue. This has been employed to particular effect in reducing the allergenicity of peach juice. Ns LTPs allergens normally find their way into juices as the peel is included in the juicing process. However, by first removing peach skins, the IgE reactivity of juices could be significantly reduced. This approach was particularly effective when a chemical lying procedure was employed (Brenna et al., 2000). Psylium husk was used as a functional ingredient in cereals because of its ability to lower cholesterol, but caused adverse reactions in individuals who had become sensitised to it through its use in bulk laxatives. By modifying the milling process to remove the parts of the seed coat which contain the allergens, the problem was overcome (Simmons, 1993). Lastly, such an approach has been used, in combination with proteolysis, to produce improved hypoallergenic infant formulas (van Beresteijn et al., 1994). Residual intact allergen in such preparations can cause reactions in some milk-allergic infants, but by employing an ultrafiltration, larger immunologically active allergen fragments can be removed.

\subsubsection{Modification of allergens by thermal treatments}

The second way in which processing (particularly thermal) can remove allergens is through denaturing the allergen, in particular by destroying conformational $\mathrm{IgE}$ epitopes. However, it is emerging that thermal process can both reduce and increase food protein allergenicity, depending on the food concerned. There may also be thermostable IgE epitopes in food proteins which are unaltered by thermal processing. One example of these is the carbohydrate residues on glycoproteins which remain unaltered by thermal processing. However, there is some doubt over the importance of carbohydrate determinants in allergy because their sparse nature means they do not offer the polyvalency necessary IgE crosslinking on mast cells and subsequent histamine release (Alberse, 1998).

A number of food proteins do not adopt a compact globular threedimensional structure, but are instead highly mobile, adopting an ensemble of conformations and their secondary structure does not melt on heating in the same fashion as globular proteins. These include the prolamin (gluten) proteins from wheat and caseins from milk. The IgE-epitopes on such proteins tend to be linear in nature and will therefore be less affected by thermal treatments than the conformational epitopes which tend to predominate on globular proteins. In addition, as summarised in section 17.1, many food allergens tend to have very stable three-dimensional structures, a property which includes thermostability. There is also evidence that whilst many of highly disulphide bonded plant proteins, like ns LTPs and $2 \mathrm{~S}$ albumins, unfold on heating they refold on cooling to an almost native structure. Hence many allergenic proteins may be able to retain both linear and conformational epitopes following mild heat-treatments below $60^{\circ} \mathrm{C}$, and their ability to trigger an allergic reaction in a sensitised individual will be essentially unaltered. This applies to many allergens, including those from soya, egg and shell-fish meat, which form the aggregates 
on heating which become incorporated into heat-set gel networks. However, due to the difficulties of working with such insoluble proteins, the IgE binding of such aggregates has not been widely studied.

For example, Ara h 1 of peanut is remarkably thermostable, unfolding to only a limited extent with many core elements in the structure remaining, as is observed for other seed storage globulins (Koppleman et al., 1999). IgE binding to wet or dry-heat denatured protein was essentially unchanged leading to the suggestion that either Ara $h 1$ does not contain any conformational epitopes, or that they are restricted to the thermostable regions of the structure. The secondary structure of another allergen, patatin (Sola $\mathrm{t} 1$, previously Sol $\mathrm{t} 1$ ) from potato, was also essentially unaltered following heating to $65^{\circ} \mathrm{C}$, as even after denaturation, it can refold on cooling (Koppleman et al., 2002). Biophysical studies showed that the loss of IgEbinding capacity on cooking results from aggregation with other potato proteins (protease inhibitors). This illustrates the importance of taking account of the behaviour of food allergens in the food matrix itself, as other components may affect the behaviour of the allergens themselves. However, as well as removing IgE epitopes, the unfolding and subsequent aggregation processes which occur in many food proteins on thermal processing, offers the possibility of introducing new epitope sites.

In summary, many of the cross-reactive allergens, such as the Bet $\mathrm{v} 1$ homologues involved in the pollen-fruit allergy syndrome, are labile proteins and are generally destroyed by cooking; allergic reactions being generally confined to raw produce. There are exceptions to this, notably a soybean homologue, SAM22, has been found to cause allergies in a processed soyabased food supplement (Kleine-Tebbe et al., 2002). Reports of sensitivity only towards processed foods are rare. One example of processing induced increases in allergenic activity was described early in the history of food allergy research, when Kustner reported his own sensitivity towards cooked but not raw, fish (Prausnitz and Kustner, 1921). In general individuals are sensitive towards both the raw and processed foods, but thermal processing may modify the degree of reactivity. Thus heating has been found to reduce the allergenicity of beef and purified bovine allergens (Fiocchi et al., 1995).

Food proteins also undergo chemical modification during thermal treatments, in particular the formation of Maillard browning adducts following severe, dry heat treatments, and during ageing of foods, which may affect food protein allergenicity (Davis et al., 2001). However, the technical difficulty of working with large aggregated protein systems has meant that the characterisation of such processing-induced epitopes has been difficult. Maillard modified peanut allergens Ara $h 1$ and Ara $h 2$ become cross-linked to form high molecular weight aggregates which bind $\operatorname{IgE}$ more effectively than unmodified allergens, and are also more resistant to gastric digestion (Maleki et al., 2000a). The allergic IgE binding towards peanut allergens Ara h 1, 2 and 3 appears to be lower in boiled and fried, compared with roasted peanuts (Beyer, 2001) indicating that certain types of thermal 
processing can introduce additional IgE binding sites. There is also a case report of pecan nut allergenicity, where the allergenic reactivity of the nut increased over time, and whilst Maillard adducts were not identified as the causative agents, it seems likely that these, or some other ageing related oxidative reaction increased the allergenicity of the nut on storage (Berrens, 1996). Other thermally induced modification, such as lactosylation of milk proteins, may play a part in altering the allergenic activity of dairy products, as the allergenic activity of $\beta$-lactoglobulin has been found to increase 100 fold following heating in the presence of lactose (Bleumink and Berrens, 1966). Thus, whilst processing of allergenic foods may not remove their allergenicity, it would increasingly appear that there are ways of reducing the allergenic potential of foods, such as peanuts, through the application of specific processing methods.

\subsubsection{Novel processing}

High-pressure processing (100-400 MPa) was used to decrease the allergenicity of rice. Under these conditions, polished rice grains released a considerable amount of proteins $(0.2-0.5 \mathrm{mg}$ per gram of grains). The major proteins released were identified, with SDS-PAGE and immunoblotting, as $16 \mathrm{kDa}$ albumin, $\alpha$ globulin, and $33 \mathrm{kDa}$ globulin, which were known as major rice allergens. Scanning electron microscopic study of rice grains pressurised at $300 \mathrm{MPa}$ demonstrated morphological changes in endosperm cells. No apparent structural changes in protein bodies were detected. The levels of the allergenic proteins mentioned by these workers were decreased by pressure treatment. Pressurisation processing in the presence of a proteolytic enzyme led to almost complete removal of the allergens. The effects can be explained by pressurisation-induced partial destruction of endosperm cells leading to enhanced permeation of the surrounding solution into rice grains. As a result, a part of the proteins is solubilised and released into the surrounding solution (Kato et al., 2000).

That high-pressure treatment is not a guarantee of success is illustrated by the unsuccessful attempt $\left(600 \mathrm{MPa}, 20^{\circ} \mathrm{C}\right)$ to reduce the IgE-binding capacity of Api g 1 from celery. Neither pulsed electric field treatment $(10 \mathrm{kV}, 50 \mathrm{~Hz})$, nor $\gamma$-irradiation (10 kGy), were effective in this respect (Jankiewicz et al., 1997).

Apparently, a complex of factors such as specific requirements for allergen structure, processing effects on tissue integrity and embedding of the allergens in the tissue matrix, determine the potential effectiveness of novel processing methods. Physical processing holds promise to reduce allergenicity in a number of cases. Better understanding of the structural relationships between various food allergens on the one hand, and respiratory and food allergens on the other hand, has the potential to rationalise and target the design of novel processing strategies for allergenicity reduction. 


\subsection{Reducing protein allergenicity using enzymatic processing}

\subsubsection{Removal of epitopes}

Prerequisites for effective reduction of allergenicity via proteolytic enzymatic treatment are sufficient contact between enzyme and target (usually implying a largely destroyed macrostructure in the food product) and sufficient substrate specificity of the protease. An important factor to take into account is to minimise the potential decrease of desirable sensory and processing properties, such as, e.g., foaming or baking properties, of the product.

Examples of unsuccessful proteolytic treatment are the difficulties encountered in reducing the allergenicity of the peanut allergen Ara $\mathrm{h} 1$ (Maleki et al., 2000b) and the major peach allergen (Brenna et al., 2000). In both cases, insufficient contact between allergen and protease explains the lack of success either because of the compact allergen structure and/or in the case of peach, intact tissue structure. Also, allergen specific characteristics may play a role in both studied cases. Ara h 1 carries at least 23 different relatively short epitopes (Burks et al., 1997), making it complicated to identify a suitable protease or protease cocktail that destroys sufficient allergenic epitopes. The major peach allergen (variously named Pru p 1 or Pru p 3) is a lipid transfer protein, a group of proteins characterised by a compact structure, which is difficult for proteases to access.

More success has been achieved in reducing wheat flour allergenicity with bromelain (Tanabe et al., 1996a; Watanabe et al., 1995). An important factor was the proper match between epitope structure (Q-X-Y-P-P) and protease specificity. Side effects on processing properties were manageable, as it was still possible to produce muffins from this flour (Tanabe et al., 1996a). Protease specificity also was a key factor in the treatment of soybeans with proteases, to reduce allergenicity. Of eight proteases tested two (Proleather and Protease N) were found to be effective in reducing $\operatorname{IgE}$ binding in soybean allergic patients. Immunoblotting with a monoclonal antibody showed that at least a major allergen (Gly $m$ Bd 30K) was affected (Yamanishi et al., 1996). As the experiments were performed on autoclaved soybeans, next to substrate specificity, also parameters such as tissue penetration and diffusion characteristics may have played a role.

Another success story is the enzymatic reduction of rice allergenicity. Watanabe et al. (1990a) and Watanabe (1993) used actinase, in combination with glycerin monooleate to facilitate endosperm penetration. The treatment resulted in a negative RAST-test, and no symptoms in six out of seven patients to which the product was clinically administered. Treatment with hydrochloric acid resulted in improved colour, while a favourable texture (stickiness/hardness score) was maintained (Watanabe et al., 1990b).

Trypsin, elastase, and a protease mixture were successfully used to decrease the allergenicity of hazelnut allergens in a crude protein extract, as demonstrated via immunoblot and EAST-inhibition. Pancreatin and pepsin appeared less 
effective in this process (Wigotzky, 2001), again suggesting that a good match between protease and allergen is important.

The conclusion seems obvious that there is a potential in protease treatment to reduce allergenicity. It is difficult to draw abstract conclusions at this stage, because of the variety in allergens and proteases on which data was reported. Additionally, factors such as ease of penetration, diffusional properties, protease specificity, etc., are to be considered. Other enzymes that have the potential to be used for this purpose are various oxidases, which contribute for instance to reduction of apple allergenicity (Wichers et al., publication in preparation).

\subsubsection{Masking of epitopes?}

Cross-linking of entire proteins, e.g., enzymatically, has resulted in the production of less allergenic food materials. Yamauchi et al. (1991) patented the cross-linking of $\alpha_{\mathrm{s} 1}$-casein by transglutaminase treatment. The cross-linked product was claimed to be less allergenic. Also wheat flour was successfully treated with transglutaminase for this purpose (Watanabe et al., 1994). Although the mechanism by which the reduction in allergenicity was achieved is not $a$ priori clear, it can be speculated that the cross-linking process will result in the 'embedding' of epitopes in the polypeptide chain, thus making them less accessible to the immune system.

\subsection{Future trends: low allergen proteins}

With rapid progress in the new research fields of genomics and in particular proteomics, it can be envisaged that our understanding of allergen structure and relationships between allergens from various sources will rapidly improve. This will shed light on allergic cross-reactions, for instance between respiratory and food allergies, and allergies for different food products. More knowledge will allow us to make better predictions of potential allergenicity.

Better understanding of allergen structure will also open up the possibility to screen in for instance germplasm collections in silico for varieties with improved properties from an allergy perspective. Such an approach might in certain cases allow avoiding the use of genetic modification, despite the promising potential of this discipline for production of hypoallergenic foods (see above). It is of note in this respect, that in many cases proteins do not lose their biological function when an antigenic or allergenic epitope is modified (Burks et al., 1999; SolerRivas and Wichers, 2001), at least suggesting that there is a fair chance that agronomical traits do not necessarily have to be influenced negatively if hypoallergenic varieties are selected.

In addition, improvements in the understanding of the relationships between protein structure and processing behaviour will allow the development of better directed food technology, also towards reduction of allergenicity. It is questionable whether food technology as such, even when better directed 
technologies can be developed with the help of improved raw material knowledge, will be sufficient in all cases to design hypoallergenic foods. However, better understanding of allergen structure and the impact of processing thereon, will also allow the development of better analytical systems to monitor the allergenic nature of food products throughout the food (processing) chain, and thus to better quality control and labelling.

\subsection{Acknowledgements}

ENCM and JAJ acknowledge the support of BBSRC through the competitive strategic grant, and through the EU (SAFE (QLK1-CT-2000-01394); Informall (QLRT-2001-02284)). JM was supported through an EU MC Fellowship (QLK1-CT-2001-51997).

\subsection{References}

ADACHI T, IZUMI H, YAMADA T, TANAKA K, TAKEUCHI S, NAKAMURA R, MATSUDA T (1993) 'Gene structure and expression of rice seed allergenic proteins belonging to the $\alpha$-amylase/trypsin inhibitor family', J Mol Biol 21, 239-248.

ALBERSE RC (1998) 'Clinical relevance of carbohydrate allergen epitopes', Allergy, 53(45 Suppl), 54-57.

ALBERSE RC (2000) 'Structural biology of allergens', J Allergy Clin Immunol, 106, 228238.

ANIBARRO BAUSELA BM, ESTEBAN MM, ALZAMORA F, PASCUAL MC, OJEDA CJ. (1991) 'Egg protein sensitization in patients with bird feather allergy', Allergy, 46, 614-618.

AYUSO R, REESE G, LEONG-KEE S, PLANTE M, LEHRER SB (2002) 'Molecular basis of arthropod cross-reactivity: IgE-binding cross-reactive epitopes of shrimp, house dust mite and cockroach tropomyosins', Int Arch Allergy Immunol 129, 38-48.

BANDO N, TSUJI H, YAMANISHI R, NIO N, OGAWA T. (1996) 'Identification of the glycosylation site of a major soybean allergen, Gly m Bd 30K', Biosci Biotechnol Biochem. 60, 347-348.

BANNON GA, SHIN D, MALEKI S, KOPPER R, BURKS AW (1999) 'Tertiary structure and biophysical properties of a major peanut allergen, implications for the production of a hypoallergenic protein', Int Arch Allergy Immunol 118, 315-316.

BERRENS L (1996) 'Neoallergens in heated pecan nut: products of Maillard type degradation?' Allergy, 51, 277-278.

BEYER K, MORROW E, LI X-M, BARDINA L, BANNON GA, BURKS AW, SAMPSON HA (2001). 'Effects of cooking methods on peanut allergenicity', J Allergy Clin Immunol, 107(6), 1077-81.

BEYER K, BARDINA L, GRISHINA G, SAMPSON HA (2002a) 'Identification of sesame seed allergens by 2-dimensional proteomics and Edman sequencing: Seed storage proteins as common food allergens', J Allergy Clin Immunol, 110, 154-159.

BEYER K, GRISHINA G, BARDINA L, GRISHIN A, SAMPSON HA (2002b) 'Identification of an $11 \mathrm{~S}$ globulin as a major hazelnut food allergen in hazelnut-induced systemic 
reactions', J Allergy Clin Immunol, 110, 517-23.

BHALLA PL, SWOBODA I, SINGH MB (1999) 'Antisense-mediated silencing of a gene encoding a major ryegrass pollen allergen', Proc Natl Acad Sci USA 96, 1167611680.

BLEUMINK E, BERRENS L (1966) 'Synthetic approaches to the biological activity of $\beta$ lactoglobulin in human allergy to cow's milk' Nature, 212, 541-543.

BREITENEDER H, EBNER C (2000) 'Molecular and biochemical classification of plantderived food allergens', J Allergy Clin Immunol, 106, 27-36.

BRENNA O, POMPEI C, ORTOLANI C, PRAVETTONI V, FARIOLI L, PASTORELLO EA (2000) 'Technological processes to decrease the allergenicity of peach juice and nectar', J Agric Food Chem, 48, 493-497.

BUGAJSKA-SCRETTER A, ELFMAN L, FUCHS T, KAPIOTIS S, RUMPOLD H, VALENTA R, SPITZAUER S (1998) 'Parvalbumin, a cross-reactive fish allergen, contains IgEbinding epitopes sensitive to periodate treatment and $\mathrm{Ca}^{2+}$ depletion', J Allergy Clin Immunol, 101, 67-74.

BURKS AW, MALLORY SB, WILLIAMS LW, SHIRRELL MA (1988) 'Atopic dermatitis: clinical relevance of food hypersensitivity reactions', J Pediatr, 113, 447-451.

BURKS AW, WILLIAMS LW, HELM RM, CONNAUGHTON C, COCKRELL G, O'BRIEN T (1991) 'Identification of a major peanut allergen, Ara h I, in patients with atopic dermatitis and positive peanut challenges', J Allergy Clin Immunol, 88, 172-179.

BURKS AW, WILLIAMS LW, CONNAUGHTON C, COCKRELL G, O'BRIEN TJ, HELM RM (1992) 'Identification and characterization of a second major peanut allergen, Ara $h I I I$, with use of the sera of patients with atopic dermatitis and positive peanut challenge', J Allergy Clin Immunol, 90, 962-969.

BURKS AW, SHIN D, COCKRELL G, STANLEY JS, HELM RM, BANNON GA (1997) 'Mapping and mutational analysis of the IgE-binding epitopes on Ara $\mathrm{h} 1$, a legume vicilin protein and a major allergen in peanut hypersensitivity', Eur $J$ Biochem 245, 334-339.

BURKS AW, HELM RM, COCKRELL G, BANNON GA, STANLEY JS, SHIN DS et al. (1999) 'Tertiary structure of peanut allergen Ara h 1', PTC Patent Application, Board of Trustees of the University of Arkansas.

BUSH RK, HEFLE SL (1996) 'Food allergens', CRC Critical Reviews in Food Science and Nutrition, 36 (Suppl), S119-163.

BUSSE PJ, JARVINEN KM, VILA L, BEYER K, SAMPSON HA (2001) 'Identification of sequential IgE-binding epitopes on bovine alpha(s2)-casein in cow's milk allergic patients', Int Arch Allergy Immuno. 129, 93-96.

CARBONERO P, GARCÍA-OLMEDO F (1999) 'A multigene family of trypsin/ $\alpha$-amylase inhibitors from cereals', in Seed Proteins pp. 617-633, Shewry PR Casey R (eds) Kluwer Academic Publishers, Dordrecht, The Netherlands.

CHATCHATEE P, JARVINEN KM, BARDINA L, BEYER K, SAMPSON HA (2001a) 'Identification of IgE- and IgG-binding epitopes on alpha(s1)-casein: differences in patients with persistent and transient cow's milk allergy', J Allergy Clin Immunol 107, 379-383.

CHATCHATEE P, JARVINEN KM, BARDINA L, VILA L, BEYER K, SAMPSON HA (2001b) 'Identification of IgE and IgG binding epitopes on beta- and kappa-casein in cow's milk allergic patients', Clin Exp Allergy. 31, 1256-1262.

COOKE SK, SAMPSON HA (1997) 'Allergenic properties of ovomucoid in man', $J$ Immunol. 159, 2026-2032.

DAVIS PJ, SMALES CM, JAMES DC (2001). 'How can thermal processing modify the 
antigenicity of proteins?', Allergy, 56 (Suppl 67), 56-60.

DODO H, MARSIC D, CALLENDER M, CEBERT E, VIQUEZ O (2002) 'Screening 34 peanut introductions for allergen content using ELISA', Food Agric Immunol, 14, 147154.

DOULIEZ J-P, MICHON T, ELMORJANI K, MARION D (2000) 'Structure, biological and technological function of lipid transfer proteins and indolines, the major lipid binding proteins from cereal kernels', J Cereal Sci, 32, 1-20.

DUNWELL JM (1998) 'Cupins: a new superfamily of functionally diverse proteins that include germins and plant storage proteins', Biotechnol Genet Eng Rev, 15, 1-32.

EIGENMANN PA, BURKS AW, BANNON GA, SAMPSON HA (1996) 'Identification of unique peanut and soy allergens in sera adsorbed with cross-reacting antibodies', $J$ Allergy Clin Immunol, 98, 969-978.

FIOCCHI A, RESTANI P, RIVA E, RESTELLI AR, BIASUCCI G, GALLI CL, GIOVANNI M (1995) 'Meat allergy II - Effects of food processing and enzymatic digestion on the allergenicity of bovine and ovine meats', J Am College Nutr, 14, 245-250.

HEFLE SL (1996) 'The chemistry and biology of food allergens', Food Technol, 50, 88-92. HOFFMANN-SOMMERGRUBER K (2002) 'Pathogenesis-related (PR)-proteins identified as allergens', Biochem Soc Trans 30, 930-935.

HONG SJ, MICHAEL JG, FEHRINGER A, LEUNG DY (1999) 'Pepsin-digested peanut contains T-cell epitopes but no IgE epitopes', J Allergy Clin Immunol 104, 473478.

JAMES JM, SIXBEY JP, HELM RM, BANNON GA, BURKS AW (1997) 'Wheat $\alpha$-amylase inhibitor: A second route of allergic sensitisation', J Allergy Clin Immunol, 99, 239-244.

JANKIEWICZ A, BALTES W, BÖGL KW, DEHNE LI, JAMIN A, HOFFMANN A, HAUSTEIN D, VIETHS S (1997) 'Influence of food processing on the immunochemical stability of celery allergens', J Sci Food Agr 75, 359-70.

JARVINEN KM, BEYER K, VILA L, CHATCHATEE P, BUSSE PJ, SAMPSON HA (2002) 'Bcell epitopes as a screening instrument for persistent cow's milk allergy', $J$ Allergy Clin Immunol. 110, 293-7.

JI C, BOYD C, SLAYMAKER D, OKINAKA Y, TAKEUCHI Y, MIDLAND SL, SIMS JJ, HERMAN E, KEEN N (1998) 'Characterisation of a 34-kDa soybean binding protein for the syringolide elicitors', proc Natl Acad Sci USA 95(6): 3306-11.

KATO T, KATAYAMA E, MATUSBARA S, OMI Y, MATSUDA T (2000) 'Release of allergenic proteins from rice grains induced by high hydrostatic pressure', J Agric Food Chem 48, 3124-3129.

KELLY JD, HLYWKA JJ, HEFLE SL (2000) 'Identification of sunflower seed IgE-binding proteins', Int Arch Allergy Immunol 121, 19-24.

KLEBER JT, CRAMERI R, APPENZELLER U, SCHLAAK M, BECKER WM (1999). 'Selective cloning of peanut allergens, including profilin and $2 \mathrm{~S}$ albumins, by phage display technology', Int Arch All Immunol 119, 265-274.

KLEINE-TEBBE J, VOGEL L, CROWELL DN, HAUSTEIN UF, VIETHS S (2002) 'Severe oral allergy syndrome and anaphylactic reactions caused by a Bet v 1- related PR-10 protein in soybean, SAM22', J Allergy Clin Immunol, 110, 797-804.

KOPPELMAN SJ, BRUIJNZEEL-KOOMEN CA, HESSING M, DE JONGH HH (1999) 'Heatinduced conformational changes of Ara h 1, a major peanut allergen, do not affect its allergenic properties', J Biol Chem 274, 4770-4777.

KOPPLEMAN SJ, VAN KONINGSVELD GA, KNULST A, GRUPPEN H, PIGMANS IGA, DE JONGH HHJ (2002) 'Effect of heat-induced aggregation on the IgE binding of 
patatin (Sol t 1) is dominated by other potato proteins', J Agric Food Chem, 50, 1562-1568.

LARSEN JN, LOWENSTEIN H (1996) 'Allergen nomenclature', J Allergy Clin Immunol 97 , 577-578.

LAWRENCE MC, IZARD T, BEUCHAT M, BLAGROVE RJ, COLMAN PM (1994) 'Structure of phaseolin at $2.2 \AA$ resolution. Implications for a common vicilin/legumin structure and the genetic engineering of seed storage proteins', J Mol Biol 238, $748-776$.

LEHRER SB, HORNER WE, REES G (1996) 'Why are some proteins allergenic? Implications for biotechnology', Crit Rev Food Sci Nutr 36, 553-564.

LEUNG PS, CHOW WK, DUFFEY S, KWAN HS, GERSHWIN ME, CHU KH (1996) 'IgE reactivity against cross-reactive allergen in crustacea and mollusca: evidence for tropomyosin as the common allergen', J Allergy Clin Immunol, 5 (pt 1) 483-487.

LI-SHAN H, MOOS M, YUAN L (1995) 'Characterization of apple 18 and $31 \mathrm{kd}$ allergens by microsequencing and evaluation of their content during storage and ripening', $J$ Allergy Clin Immunol, 96, 960-970.

LUNARDI C, NANNI L, TISO M, MINGARI MC, BASON C, OLIVERI M, KELLER B, MILLO R, DE SANDRE G, CORROCHER R, PUCCETTI A (2000) 'Glycine-rich cell wall proteins act as specific antigen targets in autoimmune and food allergic disorders', Int Immunol, 12, 647-657.

MALEKI SJ, CHUNG S-Y, CHAMPAGNE ET, RAUFMAN J-P (2000a) 'The effects of roasting on the allergenic properties of peanut proteins' $J$ Allergy Clin Immunol $106,763-768$.

MALEKI SJ, KOPPER RA, SHIN DS, PARK C-W, COMPADRE CM, SAMPSON H, BURKS AW, BANNON GA (2000b) 'Structure of the major peanut allergen Ara h 1 may protect IgE-binding epitopes from degradation', J Immunol 164, 5844-5849.

MANTYJARVI R, RAUTIAINEN J, VIRTANEN T (2000) 'Lipocalins as allergens', Biochim Biophy Acta, 1482(1-2), 308-317.

MARUYAMA N, ICHISE K, KATSUBE T, KISHIMOTO T, KAWASE S-I, MATSUMURA Y, TAKEUCHI Y, SAWADA T, UTSUMI S (1998) 'Identification of major wheat allergens by means of the Escherichi coli expression system', Eur J Biochem, 255, 739-745.

MATSUDA T, NAKAMURA R (1993) 'Molecular structure and imunological properties of food allergens', Trends Food Sci Tech 4, 289-93.

MENENDEZ-ARIAS L, MONEO I, DOMINGUEZ J, RODRIGUEZ R (1988) 'Primary structure of the major allergen of yellow mustard (Sinapis alba L.) seed, Sin a I', Eur $J$ Biochem, 177, 159-166.

MIDORO-HORIUTI T, BROOKS EG, GOLDBLUM RM (2001) 'Pathogenesis-related proteins of plants as allergens', Ann Allerg Asthma Immunol 87, 261-271.

MILLS ENC, MADSEN C, SHEWRY PR, WICHERS HJ (2003) 'Food Allergens of Plant Origin - The Relationship between Allergenic Potential and Biological Activity (PROTALL)', Trends Food Sci Technol 14, 145-156.

MILLS ENC, JENKINS JA, ROBERTSON JA, GRIFFITHS-JONES S, SHEWRY PR 'Identification and prediction of allergenic proteins in plants' in Pesticides, veterinary and other chemical residues in food, D Watson (ed.) Woodhead Publishing, (in press).

MIZUMACHI K, KURISAKI J (2003) 'Localization of T cell epitope regions of chicken ovomucoid recognized by mice', Biosci Biotechnol Biochem. 67, 712-719.

MONSALVE RI, GONZALEZ DE LA PENA MA, MENEZES-ARIAS L, LOPEZ-OTIN C, 
VILLALBA M, RODRIGUEZ R (1993) 'Characterization of a new oriental-mustard (Brassica-juncea) allergen Bra j I: detection of an allergenic epitope', Biochem. J. 293, 625-632.

NISHIYAMA I, OOTA T (2002) 'Varietal difference in actinidin concentration and protease activity in the kiwi fruit juice', J Jap Soc Food Sci Technol 49, 401-408.

OGAWA T, TSUJI H, BANDO N, KITAMURA K,ZHU Y-L, HIRANO H, NISHIKAWA K (1993)

'Identification of the soyabean allergenic proteins, Gly $\mathrm{m} \mathrm{Bd} 30 \mathrm{~K}$, with the soybean seed 34kDa oil-body-associated protein', Biosci Biotech Biochem, 57, 1030-1033.

OGAWA T, SAMOTO M, TAKAHASHI K (2000) 'Soybean allergens and hypoallergenic soybean products', J Nutr Sci Vitaminol, 46, 271-9.

PALOSUO K, ALENIUS H, VARJONEN E, KOIVULUHTA M, MIKKOLA J, KESKINEN H, KALKKINEN N, REUNALA T (1999) 'A novel wheat gliadin as a cause of exerciseinduced anaphylaxis', J Allergy Clin Immunol, 103, 912-917.

PASCHKE A, KINDER H, ZUNKER K, WIGOTZKI M, WESSBECHER R, VIELUF D, STEINHART H (2001) 'Characterisation of allergens in mango fruit and ripening dependence of the allergenic potency', Food Agric Immunol, 13, 51-61.

PASCUAL CY, ESTEBAN M, CRESPO JF (1992) 'Fish allergy: evaluation of the importance of cross-reactivity', J Paediatr 121, 29-34.

PASTORELLO EA, CONTI A, PRAVETTONI V, FARIOLI L, RIVOLTA F, ANSALONI R, ISPANO M, INCORVAIA C, GIUFFRIDA MG, ORTOLANI C (1998a) 'Identification of actinidin as the major allergen of kiwi fruit', J Allergy Clin. Immunol. 101, 531537.

PASTORELLO EA, FARIOLI L, PRAVETTONI V, ISPANO M, CONTI A, ANSALONI R, ROTONDO F, INCORVAIA C, BENGTSSON A, RIVOLTA F, TRAMBAIOLI C, PREVIDI M, ORTOLANI C (1998b) 'Sensitization to the major allergen of Brazil nut is correlated with the clinical expression of allergy', J Allergy Clin Immunol 102, 1021-1027.

PASTORELLO EA, POMPEI C, PRAVETTONI V, BRENNA O, FARIOLI L, TRAMBAIOLI C, CONTI A (2001a) 'Lipid transfer proteins and 2S albumins as allergens', Allergy 56 (Suppl 67), 45-57.

PASTORELLO EA, VARIN E, FARIOLI L, PRAVETTONI V, ORTOLANI C, TRAMBAIOLI C, FORTUNATO D, GIUFFRIDA MG, RIVOLTA F, ROBINO A, CALAMARI AM, LACAVA L, CONTI A (2001b) 'The major allergen of sesame seeds (Sesamum indicum) is a 2S albumin', J Chromatogr B Biomed Sci Appl 756, 85-93.

POLTRONIERI P, CAPPELLO MS, DOHMAE N, CONTI A, FORTUNATO D, PASTORELLO EA, ORTOLANI C, ZACHEO G (2002) 'Identification and characterisation of the IgE-binding proteins $2 \mathrm{~S}$ albumin and conglutin gamma in almond (Prunus dulcis) seeds', Int Arch Allergy Immunol, 128, 97-104.

PRAUSNITZ C, KUSTNER H (1921) 'Studies on supersensitivity' Centralbl f Bacteriol 1 Abt Orig, I 86, 160-169.

RABJOHN P, HELM EM, STANLEY JS, WEST CM, SAMPSON HA, BURKS AW, BANNON GA (1999) 'Molecular cloning and epitope analysis of the peanut allergen Ara h 3', $J$ Clin Invest 103, 535-542.

REESE G, JEOUNG BJ, DAUL CB, LEHRER SB (1997) 'Characterization of recombinant shrimp allergen Pen a 1 (tropomyosin)', Int Arch Allergy Immunol 113, 240-242.

ROUX KH, TEUBER SS, ROBOTHAM JM, SATHE SK (2001) 'Detection and stability of the major almond allergen in foods', $J$ Agric Food Chem 49, 2131-2136.

SAMOTO M, MIYAZAKI C, AKASAKA T, MORI H, KAWAMURA Y (1996) 'Specific 
binding of allergenic soybean protein Gly m Bd 30K with $\alpha^{\prime}$ and $\alpha$-subunits of conglycinin in soy milk', Biosci Biotech Biochem, 60, 1006-1010.

SÁNCHEZ-MONGE R, LOMBARDERO M, GARCIA-SELLÉS FJ, BARBER D, SALCEDO G (1999) 'Lipid-transfer proteins are relevant proteins in fruit allergy', J Allergy Clin Immunol, 103(3), 514-519.

SÁNCHEZ-MONGE R, PASCUAL CY, DIAZ-PERALES A, FERNANDEZ-CRESPO J, MARTINESTEBAN M, SALCEDO G (2000) 'Isolation and characterisation of relevant allergens from boiled lentils', J Allergy Clin Immunol 106, 955-961.

SHANTI KN, MARTIN BM, NAGPAL S, METCALFE DD, SABBA RAO PV (1993) 'Identification of tropomyosin as the major shrimp allergen and characterization of its IgE binding epitopes', $J$ Immunol 151, 5354-5363.

SHEWRY PR, TATHAM AS (1990) 'The prolamin storage proteins of cereal seeds: structure and evolution', Biochem J 267, 1-12.

SHEWRY PR, TATHAM AS (1999) 'The characterisation, structures and evolutionary relationships of prolamins' in: Seed Proteins pp. 11-33. Shewry PR, Casey R (eds) Kluwer Academic Publishers, Dordrecht.

SHIBASAKI M, SUZUKI S, TAJIMA S, NEMOTO H, KUROUME T (1980) 'Allergenicity of major component proteins of soybean', Int Arch Allergy Appl Immunol, 61, 441448.

SIMMONS CT (1993) 'Method of decreasing the allergenicity of psyllium seed husk', USA Patent Number 5,273,764.

SOLER-RIVAS C, WICHERS HJ (2001) 'Impact of (bio)chemical and physical procedures on food allergen stability', Allergy 56 Suppl 67, 52-55.

SON DY, SCHEURER S, HOFFMAN A, HAUSTEIN D, VIETHS S (1999) 'Pollen-related food allergy: coning and immunological analysis of isoforms and mutant of Mal $\mathrm{d} 1$, the major apple allergen, and Bet v 1, the major birch pollen allergen', Eur J Nutr,38, $201-215$.

SUSZKIW J (2002) 'Researchers develop first hypoallergenic soy beans', Agric Res Mag, $50(9), 16-17$.

TADA Y, NAKASE M, ADACHI T, NAKAMURA R, SHIMADA H, TAKAHASHI M, FUJIMURA T, MATSUDA T (1996) 'Reduction of allergenic proteins in transgenic rice plants by antisense gene', FEBS-Lett, 391, 341-345.

TAKIZAWA T, ARAKAWA H, TOKUYAMA K, MORIKAWA A (2001) 'Identification of allergen fractions of wheat flour responsible for anaphylactic reactions to wheat products in infants and young children', Int Arch Allergy Immunol 125, 51-56.

TANABE S, ARAI S, WATANABE M (1996a) 'Modification of wheat flour with bromelain and baking hypoallergenic bread with added ingredients', Biosci Biotech Biochem, 60, 1269-1272.

TANABE S, ARAI S, YANAGIHARA Y, TAKAHASHI K, WATANABE M (1996b) 'A major wheat allergen has a Gln-Gln-Gln-Pro-Pro motif identified as an IgE-binding epitope', Biochem Biophys Res Commun, 219, 290-293.

TAYLOR SL, HEFLE SL (2001) 'Food allergies and other food sensitivities', Food Technol, 55, 68-83.

TAYLOR SL, LEHRER SB (1996) 'Principles and characteristics of food allergens', Crit Rev Food Sci Nutr, 36(S), S91-S118.

TAYLOR SL, LEMANSKI RF, BUSH RK, BUSSE WW (1987) 'Food allergens: structure and immunologic properties', Ann Allergy, 59, 93-99.

TEUBER SS, PETERSEN WR (1999) 'Systemic allergic reaction to coconut (Cocos nucifera) in 2 subjects with hypersensitivity to tree nut and demonstration of cross- 
reactivity to legumin-like seed storage proteins: new coconut and walnut food allergens', J Allergy Clin Immunol 103, 1180-1185.

TEUBER SS, DANDEKAR AM, PETERSON WR, SELLERS CL (1998) 'Cloning and sequencing of a gene encoding a $2 \mathrm{~S}$ albumin seed storage protein precursor from English walnut (Juglans regia), a major food allergen', J Allergy Clin Immunol $101,807-814$.

TEUBER S, JARVIS KC, DANDEKAR AM, PETERSON WR, ANSARI A (1999) 'Identification and cloning of a complementary DNA encoding a vicilin-like proprotein, Jug $\mathrm{r} 2$, from English walnut kernel (Juglans regia), a major food allergen', J Allergy Clin Immunol 104, 1111-1120.

TSAI YT, CHEN SH, LIN KL, HSIEH KH (1990) 'Rice pollen allergy in Taiwan', Ann Allergy 65, 459-462.

URISU A, YAMADA K, MASUDA S, KOMADA H, WADA E, KONDO Y, HORIBA F, TSURUTA M, YASAKI T et al. (1991) '16 kilodalton rice protein is one of the major allergens in rice grain extract and responsible for cross-allergenicity between cereal grains in the Poaceae family', Int Arch Allergy Appl Immunol, 96, 244-252.

VAN BERESTEIJN ECH, PEETERS RA, KAPER J, MEIJER RJG, ROBBEN AJPM, SCHMIDT DG (1994) 'Molecular mass distribution, immunological properties and nutritive value of whey protein hydrolysates', J Food Sci, 57, 619-625.

VIETHS S, SCHONING B, JANKIEWICZ A (1993) 'Occurrence of IgE binding allergens during ripening of apple fruits', Food Agric Immunol, 5, 93-105.

VIOQUE J, SANCHEZ-VIOQUE R, CLEMENTE A, PEDROCHE J, BAUTISTA J, MILLAN F (1999) 'Purification and partial characterization of chickpea 2S albumin', J Agric Food Chem, 47, 1405-1409.

WAL J-M (1998) 'Cow's milk allergens', Allergy, 53, 1013-1022.

WANG F, ROBOTHAM JM, TEUBER SS, TAWDE P, SATHE SK, ROUX KH (2002) 'Ana o 1, a cashew (Anacardium occidental) allergen of the vicilin seed storage protein family', J Allergy Clin Immunol, 110, 160-166.

WATANABE M (1993) 'Hypoallergenic rice as a physiological functional food', Trends Food Sci Technol, 4, 125-128.

WATANABE M, MIYAKAWA J, IKEZAWA Z, SUZUKI Y, HIRAO T, YOSHIZAWA T, ARAI S (1990a). 'Production of hypoallergenic rice by enzymatic decomposition of constituent proteins', J Food Sci, 55, 781-783.

WATANABE M, YOSHIZAWA T, MIYAKAWA J, IKEZAWA Z, ABE K, YANAGISAWA T, ARAI S (1990b) 'Quality improvement and evaluation of hypoallergenic rice grains', J Food Sci 55, 1105-1107.

WATANABE M, SUZUKI T, IKEZAWA Z, ARAI S (1994) 'Controlled enzymatic treatment of wheat proteins for production of hypoallergenic flour', Biosci Biotech Biochem 58, 388-390.

WATANABE M, TANABE S, SUZUKI T, IKEZAWA Z, ARAI S (1995) 'Primary structure of an allergenic peptide occurring in the chymotryptic hydrolysate of gluten', Biosci Biotech Biochem 59, 1596-1597.

WIGOTZKI M (2001) 'Einfluß der technologischen Verarbeitung auf das allergene Potential der birkenpollenassozierten Lebensmittel Haselnuß, Apfel und Karotte' (thesis). University of Hamburg, Germany.

XU H, THEERAKULPISUT P, GOULDING N, SUPHIOGLU C, SINGH MB, BHALLA PL (1995) 'Cloning, expression and immunological characterisation of Ory s 1 , the major allergen of rice pollen', Gene, 164, 255-259.

YAKLICH RW, HELM RM, COCKRELL G, HERMAN EM (1999) 'Analysis of the 


\section{Proteins in food processing}

distribution of the major soybean seed allergen in a core collection of Glycine max accessions', Crop Sci, 39, 1444-1447.

YAMADA K, URISU A, KOMADA H, INAGAKI Y, YAMADA M, NAKAMURA R, TORII S (1991) 'The involvement of rice protein $16 \mathrm{kD}$ in cross-allergenicity between allergens in rice, wheat, corn, Japanese millet, Italian millet', Jap J Allergol, 40, 1485-1492.

YAMANISHI R, TSUJI H, BANDO N, YAMADA Y, NADAOKA Y, HUANG T, NISHIKAWA K, EMOTO S, OGAWA T (1996) 'Reduction of allergenicity of soybean by treatment with proteases', J Nutr Sci Vitaminol 42, 581-587.

YAMAUCHI K, UENIKAWA S, ENOMOTOT A, TANIMOTO H, OOHATA K, MOTOKI M (1991) 'Transglutaminase for reducing allergenicity of food proteins and/or peptides and method for reducing their allergenicity', Jpn. Kokai Tokkhyo Koho JP 0327253.

YOULE RJ, HUANG AHC (1981) 'Occurrence of low molecular weight and high cysteine containing albumin storage proteins in oilseeds of disperse species', Am J Botany, $68,44-48$. 